Stefan Radziszewski

Wyższa Szkoła Handlowa w Radomiu

Niech nie gada!

(Judasz o Jezusie) $)^{1}$.

Judasz, daj srebrniki, bo jak nie, to w morde (z cyklu: „Wspomnienia Judasza z dzieciństwa”)2.

\title{
WITAJ, JUDASZU. DRAMAT ZAGUBIONEGO APOSTOŁA W JUDASZU Z KARIOTHU KAROLA HUBERTA ROSTWOROWSKIEGO
}

Zdrada na zdradzie i zdradą pogania! Tak wygląda współczesny świat. Wierność stała się cnotą zapomnianą, a Judasz - symbol zdrady, arcyzdrajca, niegodziwy apostoł, ten, w którego wstąpił szatan (zob. J 13,X)27) - stał się bohaterem naszych czasów. Artyści przez wieki przedstawiali go jako człowieka pełnego skrywanej nienawiści, który siedzi osobno, bez aureoli, a u Giotta i Fra Angelica ma nawet rudą brodę i czarną aureolę. Jego atrybut stanowi sakiewka z trzydziestoma srebrnikami, zapłatą za haniebny czyn ${ }^{3}$. W niniejszym opracowaniu próbuję przedstawić postać Judasza w pięcioaktowym dramacie Karola Huberta Rostworowskiego, pt. Judasz z Kariothu (1913), powstałym u schyłku modernizmu4

${ }^{1}$ K. H. Rostworowski, Judasz z Kariothu, w: tegoż, Wybór dramatów, oprac. J. Popiel, Wrocław 1992, s. 7 (dalej cytowane poprzez podanie numeru aktu, sceny i wersetu, np. III, 2, w. 16; natomiast w akcie III zaznaczam podział na dwie odsłony: Portyk Salomona - III-1 oraz Bethania - III-2).

${ }^{2}$ I. Iredyński, Żegnaj, Judaszu..., w: tegoż, Dziewięć wieczorów teatralnych. Wybór utworów scenicznych, Kraków 1986, s. 60 (pierwodruk: „Dialog” 1965, nr 9, s. 25-44).

${ }^{3}$ Zob. P. Sellier, Biblia w kulturze Zachodu, przeł. E. Burska, Warszawa 2012, s. 212.

${ }^{4}$ Data powstania dramatu nie świadczy bynajmniej o tym, iż autor Judasza z Kariothu jest epigonem Młodej Polski. Czytając jego dramat, warto podziwiać ,żelazną konstrukcję, lapidarność słowa, maestrię w stopniowaniu napięć, wizjonerstwo charakterologiczne, 
Biblijny Judasz Iskariota „cieszył się” dużą popularnością wśród twórców Młodej Polski ${ }^{5}$. Obok poematu w formie monologu Judasz Jana Kasprowicza i powieści Maria Magdalena Gustawa Daniłowskiego, w epoce Młodej Polski pojawiają się trzy głośne dramaty o apostole zdrajcy. Schyłek modernizmu przynosi Judasza z Kariothu Karola Huberta Rostworowskiego, Judasza Kazimierza Przerwy-Tetmajera i poemat dramatyczny Maria z Magdali Antoniego Szandlerowskiego ${ }^{6}$. Rostworowski pisze swoje dzieło niejako w opozycji do Daniłowskiego i Szandlerowskiego, niechętnie odnosząc się do wprowadzania do biografii Judasza wątków romantycznych (czy erotycznych), wedle których Iskariota (zakochany w Marii Magdalenie) zdradza Jezusa, który jest konkurentem w zmaganiach o serce Marii z Magdali ${ }^{7}$. Jego Judasz to „nędzarz, któremu się uśmiecha zmiana losu, uznaje tylko cele ziemskie [...] nie mogąc zbliżyć się duchowo do Chrystusa, pragnie Go wciągnąć na poziom swego politycznego kuglarstwa, spekuluje na psychologii tłumu, służy sprytem, przebiegłością i kłamstwem"8. Judasz Rostworowskiego jest również nieszczęsnym człowiekiem, którego tragedia dotyka czytelnika i widza ${ }^{9}$, ale nie jest Judaszem - bohaterem modernistycznych dywagacji, w którym żyją typowe problemy epoki (mniej „Judasza”, a więcej Schopenhauera, Przybyszewskiego i innych balastów modernizmu), w którym

odwagę balansowania na wąskiej krawędzi między tragedią i sensacją" (L. Eustachiewicz, Wokół K. H. Rostworowskiego, „Dialog” 1969, nr 6, s. 149).

${ }^{5}$ „Skąd w literaturze Młodej Polski taka wielość i różnorodność spojrzeń na bohaterów biblijnych? [...] Zrodziły je pesymizm i zwątpienie [...] Pesymizm ciąży nad całym światem modernistycznej literatury, ale Biblia dała mu największą chyba siłę wyrazu. To właśnie pesymizm i związane z nim tendencje czy też „,mody” epoki, takie jak nihilizm i dekadentyzm, poczucie schyłkowości, katastrofizm, erotyzm, rozumiany jako dzieło instynktu, i mizoginizm, tak znamienny dla dzieł modernistów, przetworzyły obraz biblijny w dolinę łez i cierpienia" (J. Jędrusiak, Motyw Judasza w dramacie Młodej Polski, w: Dramat biblijny Młodej Polski, red. S. Kruk, Wrocław 1992, s. 197).

${ }^{6}$ Zob. J. Jędrusiak, dz. cyt., s. 195-196.

${ }^{7}$ Zob. tamże, s. 225.

${ }^{8}$ H. Życzyński, Twórczość Karola Huberta Rostworowskiego, Lublin 1938, s. 10.

9 „Judasz Rostworowskiego jest ,człowiekiem zwyczajnym”, który pragnął pogodzić swój plan życia ziemskiego z planem Boga, jaki realizował się w życiu Chrystusa. W efekcie splotu dramatycznych wydarzeń musiał dokonać jednak ważnego wyboru między tymi dwoma drogami. Decyzja okazała się tragiczna: oznaczała w każdym wypadku bolesną konieczność wyrzeczenia się siebie, pójście za Jezusem było bowiem drogą pokory a wyrzeczeniem się pychy, natomiast zdrada Jezusa stawała się równocześnie unicestwieniem siebie jako człowieka, który w planie Boga przeznaczony został do miłości innych ponad miłość własną" (W. Kaczmarek, Zdrada i wiara (Karol Hubert Rostworowski), w: tegoż, Złamane pieczęcie Księgi. Inspiracje biblijne $w$ dramaturgii Młodej Polski, Lublin 1999, s. 274). 
niewiele zostało z realnego Iskarioty ${ }^{10}$. „Judasz-sklepikarz jest w koncepcji Rostworowskiego sumienny i uczciwy [...] późniejszym życiem zmarnował łaskę; pociągnęło to $\mathrm{w}$ konsekwencji jego upadek: stał się skarbnikiem-złodziejem i zdrajcą Mistrza”"11. Bohater Judasza z Kariothu Rostworowskiego „w rzeczywistości wzbudza współczucie i litość. Do tego stopnia, że czytelnik stawia sobie pytanie, który z dwu skazańców jest bardziej nieszczęśliwy: Chrystus czy Judasz?"”2.

\section{Pejzaż z widokiem na jezioro}

Karol Hubert Rostworowski wędruje ścieżkami swojej sztuki „,w poszukiwaniu prawdy o Judaszu" ${ }^{3}$. Jego podstawowym problemem jest „logika grzechu Judasza"14. Portret apostoła zdrajcy przedstawia samotnego człowieka, który siedzi, odwrócony plecami od czytelnika/widza i patrzy w stronę jeziora Genezaret. To biedny Judasz, Judasz „frasobliwy”, przygarbiony, wpatrzony w dal, z nerwowym tikiem, który raz po raz wstrząsa jego postacią. Już w tym pierwszym spotkaniu z apostołem z Kariothu odczuwamy jego osobność, nieadekwatność jego osoby do głoszonej Dobrej Nowiny przez Proroka z Nazaretu. Akt pierwszy to przewrotna aluzja do Księgi Rodzaju, w której Rostworowski przywołuje spotkanie Boga, w postaci trzech aniołów, z biblijnym patriarchą, Abrahamem, siedzącym pod dębami Mamre (zob. Rdz 18,1-16). Tym razem to Iskariota występuje w roli głównej, nawiedzają go natomiast wysłannicy Sanhedrynu: Eleazar, Abraham i Ezra. Trzech podstępnych szpiegów nie ma w sobie nic z mężnego Abrahama, ojca wiary, wprost przeciwnie. Reprezentują Zakon, czyli prawo Mojżeszowe, którego największym wrogiem (wedle ich oceny) jest nowy prorok z Nazaretu. Stąd ich wizyta nad jeziorem Genezaret, w domu Judasza, który... ulepiony jest z tej samej gliny. Duch Starego Przymierza, pamięć o prawie Mojżeszowym, jest mocno zapisana we wnętrzu Judasza. Pierwszy akt Judasza $z$ Kariothu to starcie dwóch światów: starego Prawa (trzech wysłanników, którzy

${ }^{10}$ Zob. J. Jędrusiak, dz. cyt., s. 234. Warto dodać, że sam Rostworowski „dochodził do wiary chrześcijańskiej poprzez umysłową spekulację i filozofię, poprzez maksymalny wysiłek intelektualny. Znalazłszy w religii prawdę jedyną i bezwzględną, praktykował ją później z prostotą, pokorą i ufnością [...] W Piśmie świętym odnalazł program życia duchowego, rodzinnego i społecznego" (J. Popiel, Szkic biografii Karola Huberta Rostworowskiego, „Znak” 1984, nr 8-9, s. 1121).

${ }^{11}$ J. Starnawski, Tragizm „Judasza” Rostworowskiego, „Przegląd Powszechny” 1951, t. 231 , s. 425 .

12 J. Jędrusiak, dz. cyt., s. 233.

13 Tamże, s. 224.

${ }^{14}$ Zob. J. Kuczyńska, Z dziejów scenicznych dwu dramatów o Judaszu, w: Biblia a literatura, red. S. Sawicki, J. Gotfryd, Lublin 1986, s. 355. 
przybyli z Jerozolimy) oraz nowej nauki Jezusa z Nazaretu (ten tryptyk jest jednak bardziej skomplikowany: Judasz apostoł i jego żona, Rachela, która uwierzyła Ewangelii ${ }^{15}$, oraz Jan apostoł, umiłowany uczeń Jezusa). Okazuje się, że Judasz nie pojął i nie przyjął ducha Ewangelii, dlatego nie rozumie miłości do Jezusa, które odkrywa w Racheli i Janie.

Być może bieda duchowa Judasza wyrasta z jego biedy materialnej? W ekspozycji dramatu poznajemy Iskariotę jako ubogiego handlarza, który z trudnością wiąże koniec z końcem. Tematyka biedy Judasza powraca zresztą w akcie II dramatu:

Ojcowie. Jam tu sklepik miał.

Otwarty ledwie do wieczora.

Taki... ot, trochę ryb, kołaczy...

Różności. Towar mieszany.

I w biedzie-m był. Tu nie pany.

Tu czasem tylko zajdzie ktoś...

ot... Fenicjanin z wyrobami,

co zamiast wypić stół poplami,

a zamiast płacić? to się jeszcze proś.

I w biedzie-m był.

$$
\text { (I, 5, w. 247-257) }
$$

I te gorzkie, gorzkie łzy,

kiedy człek nad losem duma,

kiedy obliczać zaczyna:

to moje, a to wynoszę...

za co? po co? na co? komu?

jeśli mogło zostać $\mathrm{w}$ domu.

$$
\text { (II, 4, w. 260-265) }
$$

Gorsza jest jednak nędza duchowa Judasza, który stał się apostołem, ale nie potrafi do końca zaufać nauce Chrystusa. Iskariota z zazdrością patrzy na wiarę Jana - sobie zaś przypisuje jakiś rodzaj opętania, niejako profetycznie zapowiada własny upadek:

${ }^{15}$ Żona Judasza - podobnie jak w książce Janiny Hertz - nosi imię Rachela. Jednak w Judaszu z Kariothu Rachela to kobieta mądra i pobożna, która z wiarą przyjmuje orędzie Jezusa, natomiast w Mozaice z Noemi Rachela jest małostkowa i głupia, egoistyczna i obłudna, nienawidzi swojego męża i uważa, że Judasz powinien trafić do piekła; zob. S. Radziszewski, Raport w sprawie Judasza (Janiny Hertz słowo w obronie apostoła), w: W kręgu apokryfów, red. E. Jakiel, J. Mosakowski, Gdańsk 2015, s. 328. 
JUDASZ

Tyś święty!

JAN

Nie, Juda!

JUDASZ

W Tobie nie ma pychy!

A jam jest lichy! Ja przeklęty!

JAN

Nie, Juda!

$$
\text { JUDASZ }
$$

Milcz! - A we mnie siedzi...

Milcz! - Szatan. Milcz! - Szatański taniec.

(I, 8, w. 510-518)

Po tym dialogu, a właściwie wyznaniu Judasza, że należy do Szatana, następuje scena, w której Judasz chwyta Jana za rękę i przykłada ją sobie do serca: „O! Przyłóż rękę. Czujesz? Puka./ Stuka. Uderza w kości rogiem./ A wiesz ty, czemu? Drogi szuka,/ bo wciąż wojować musi z Bogiem./ I wyjść nie może. Bóg go spiął/ żyłami memi, kośćmi memi./ Więc jakże? Jestem z onym zbratan./ Wskazując niego Tam Bóg.../ Wskazując Rachele tu życie.../ Uderzajac sie w serce a tu Szatan!” (I, 8, w. 519-527). Zdaniem krytyków „sylwetkę duchową Judasza określa dominanta pierwiastka materialistycznego w znaczeniu zarówno moralnym, jak i metafizycznym, czy inaczej: pewien rodzaj „kłamstwa” etycznego, impregnującego jaźń Judaszową całkowicie na zrozumienie transcendentnych wartości Boskiego Zbawiciela i jej bezkompromisowych wobec zła imperatywów"16. Iskariota to histeryczny kramarz, którego nędzę na chwilę zatrzymuje nagłe olśnienie duchowe - bierze na ramiona ciężar ponad miarę i ugina się pod nim ${ }^{17}$. Niestety, „kresem jego heroizmu było porzucenie dla Chrystusa sklepiku w Galilei”"18.

To właśnie pęknięcie, rodzaj rozdarcia Judasza, wykorzystują trzej „pielgrzymi” z Jerozolimy. Agenci Sanhedrynu znakomicie „rozgrywają” Judasza, wykorzystują jego kompleksy i ambicje. Mistrzowsko trafiają w pragnienie wielkości

${ }^{16}$ J. Bartyzel, , Judasz z Kariothu” Karola Huberta Rostworowskiego. Dzieje recepcji scenicznej i krytycznoliterackiej (1913-1981), w: Dramat biblijny Młodej Polski, red. S. Kruk, Wrocław 1992, s. 66.

${ }^{17}$ Zob. tamże, s. 67.

${ }^{18}$ J. Popiel, Czy możliwa jest tragedia chrześcijańska? (, Judasz z Kariothu” Karola Huberta Rostworowskiego), „Znak” 1984, nr 8-9, s. 1144. 
Judasza, w jego psychiczne zagubienie i niepewność ${ }^{19}$. Z jednej strony Judasz jest wrogo nastawiony do kasty kapłańskiej, którą reprezentują jego nieoczekiwani goście:

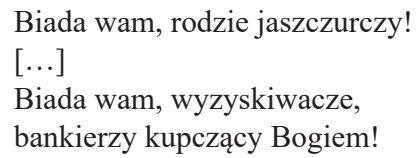

w czym zresztą przypomina swojego Nauczyciela (scena wypędzenia kupców ze świątyni, opisana w ewangelii Janowej). $Z$ drugiej jednak strony marzy mu się nie tylko wielka rewolta narodowa, wyzwolenie Izraela spod ucisku Rzymu, lecz także rewolucja ludowa, zmiana układu sił społecznych, prawie w duchu rewolucji francuskiej $(\mathrm{sic} !)^{20}$.
Umilkną Saduceusze.
Ich gromadka. Siła z nami.
A mało? to $z$ celnikami,
$\mathrm{z}$ poganami ruszym społem
i gdy tak uderzym ławą,
to im rzeź wyprawim krwawą,
to ich do milczenia zmuszę!...

$$
\text { (II, 2, w. 66-72) }
$$

Niestety, ,pomyłka Judasza tkwi w błędnym rozumieniu nauki Zbawiciela. W miejsce prawd głoszonych przez Jezusa, przekorny uczeń podstawia własne hasła podporządkowane celom, ku którym dąży" "21. Nowe przykazanie Jezusa dla apostoła zdrajcy nie jest przykazaniem miłości, ale buntowniczym hasłem, które porwie ludzi do walki o lepsze jutro, o wyzwolenie z ucisku i nędzy.

Słowa Chrystusa o miłości braterskiej zostają przez Judasza reinterpretowane, przemienią się na jego ustach w wezwanie do walki o równość,

${ }^{19}$ Studiując pełną sprzeczności osobowość Judasza, warto przywołać porównanie etyki modernizmu z etyką symbolistyczną, w którym Teresa Walas kreśli obraz bohatera pełnego ambiwalencji, tendencji immoralistycznych, ale też tęsknotę za Absolutem, posuniętą aż do pragnienia zatracenia się w nim poprzez unicestwienie (T. Walas, Dynamika wewnętrzna światopogladu Młodej Polski, w: Porównania. Studia o kulturze modernizmu, red. R. Zimand, Warszawa 1983 s. 24).

${ }^{20}$ Judasz staje się trybunem ludowym, krzyczącym do thumu: „Dzisiaj my, ludzie prości,/ rzucamy światu nowe przykazanie/ równości, bractwa i wolności!" (II, 3, 158-160).

${ }^{21}$ J. Jędrusiak, dz. cyt., s. 230. 
braterstwo i sprawiedliwość społeczną. Dlatego tak często badacze twórczości Karola Huberta Rostworowskiego będą widzieli w bohaterze tego dramatu proletariusza „walczącego o poprawę doli ludu”, marzącego o wymierzeniu sprawiedliwości znienawidzonym kapłanom ${ }^{22}$.

W przebiegły sposób agenci Sanhedrynu osaczają ambitnego apostoła - Eleazar mówi do Judasza z udawanym podziwem: „Tyś jest Juda Machabeusz/ poręką ludu wieżaty!” (II, 4, w. 254-255). Zamiast wierności nauce Jezusa, Iskariota rozpoczyna nowy rozdział swej historii: staje się przywódcą powstania, które posłuży się Mesjaszem Chrystusem, aby przejąć władzę w Izraelu. Judasz Rostworowskiego - jak słusznie pisze Jacek Bartyzel - to polityczny „impresario”, montujący partię zwolenników Jezusa, reżyserujący uroczysty wjazd do Jerozolimy, pouczający, co należy krzyczeć23. Rzesza z szacunkiem słucha instrukcji Judasza, który organizuje Niedzielę Palmową:

I jeszcze ostatni raz żebyście potem się nie pchali jak zwykle, żeby nie gadali: „ot, jakieś włóki z Galilei” ostatni raz pouczę was, niech sobie każdy zapamięta. A więc. Na czoło dać chłopięta. Niech idą. Niech zrywają kwiaty. Liście. Gałązki. Co się zdarzy. Dalej niewiasty. Dalej młódź.

Dalej Mistrz. Wkoło Apostoły.

Za nimi męże. Za mężami starzy.

W końcu zaś wszystko, co przystanie do nas po drodze.

(II, 3, w. 139-152)

Iskariota okazuje się sprytnym manipulatorem i zręcznym intrygantem. Jako demagog sprawdza się w dwójnasób i jego ukryci mocodawcy (agenci Sanhedrynu) mogą być zadowoleni z tego, jak dobrze radzi sobie ten biedny sklepikarz $\mathrm{z}$ opanowaniem emocji thumu:

JUDASZ

My, gromadka nasza, daje światu Mesyjasza

i na cześć Jego podnosi wołanie...

${ }^{22}$ Tamże.

${ }^{23}$ Zob. J. Bartyzel, dz. cyt., s. 67. 
Po chwili ze złościa

Jakież?!

RZESZA

obowiąkowo

Hosanna!

JUDASZ

sucho

Idźcie.

RZESZA

Dobrze, Panie.

(II, 3, w. 161-163)

Judasz, wcześniej „,praktyczny sklepikarz”24, rzuca się w wir pracy konspiracyjnej, próbując w ten sposób uwolnić się od wewnętrznej walki: od pragnienia pójścia za Jezusem i Jego nauką oraz demonicznym odrzuceniem Boga, wierności Mistrzowi z Nazaretu, życia we wspólnocie nowego prawa. Ta psychomachia w ujęciu Rostworowskiego nie podąża jednak śladem jego poprzedników - na próżno szukać w Judaszu z Kariothu zdrady jako skutku gry politycznej albo afery erotycznej. Judasz Rostworowskiego wierzy i nie wierzy, a właściwie inaczej: wierzy, ale wie, że jego wiara jest fałszywa, obłudna, płytka, „biedna”. Biedny Judasz czuje, że nie należy mu się miejsce na salonach, że „przelicytował” w zbyt wielkiej rozgrywce. Nie ma powołania do wielkości duchowej, a właściwie - powołany, nie potrafi odpowiedzieć szczerym i ufnym sercem ${ }^{25}$. Jest tylko „małym” człowiekiem, pod powierzchnią pozornej religijności kryje się pustka i brak wiary ${ }^{26}$. „Wiara Judasza opiera się na strachu, zaś przygotowanie uroczystego wjazdu do Jerozolimy nosi w sobie zalążek szatańskiej pychy, która każe Iskariocie osądzać Jezusa według własnej miary" ${ }^{\prime 27}$. Zdrada Judasza w dramacie Rostworowskiego nie jest więc dramatem metafizycznym, ale fatalnym upadkiem, który musiał się dokonać, odkąd jego banalny i słaby bohater wpadł

${ }^{24}$ Zob. J. Kuczyńska, dz. cyt., s. 354.

${ }^{25}$ Jak twierdzi Jacek Popiel: „Najważniejszą dla swego życia decyzję Judasz Rostworowskiego podejmuje przed podniesieniem kurtyny. Postawiony w sytuacji tragicznego wyboru: przystąpić czy nie przystąpić do Chrystusa, wybiera możliwość pierwszą. W momencie wyboru był wolny, od niego tylko zależało, czy wypełni się jego tragedia. Źródłem losu Judasza jest przede wszystkim jego własny charakter [...] Judasz był ograniczony, mały, tchórzliwy, powołany do egzystencji wymodelowanej zwrotem Jam w Galilei sklepik mial' (J. Popiel, Czy możliwa jest tragedia ..., s. 1135-1136).

${ }^{26}$ J. Jędrusiak, dz. cyt., s. 226.

${ }^{27}$ Tamże, s. 227. 
w mechanizmy odwiecznych planów zbawienia. Judasz handlarz, lichy sklepikarz, nie mógł wypłynąć na szerokie wody, by łowić ludzi, bowiem nie miał w sobie duszy rybaka. Jak pisze Starnawski: „nie potwora i nie wyrodka ukazał poeta, ale żywego człowieka, małego i skromnego, przyziemnego, szarego i nieszczęśliwego, człowieka, który swą małostkową, kramarską duszą nie dorósł do świętego posłannictwa apostoła Chrystusowego"28.

\section{Golgota apostoła zdrajcy}

Tak naprawdę Judasz nigdy nie zrozumiał Chrystusa, bo nie chciał Go zrozumieć, a nawet można by powiedzieć, iż Judasz „umarł” dla Chrystusa, zanim jeszcze stał się współwinnym śmierci Zbawiciela ${ }^{29}$. Jacek Bartyzel twierdzi, że Rostworowski w swojej wersji historii Judasza definiuje zło podobnie jak św. Augustyn: zło stanowi brak dobra, jest rodzajem defektu, niezdolnością do realizacji powołania ${ }^{30}$. Judasz zagubiony, rozdarty pomiędzy światem Starego Prawa, do którego należy, a światem Jezusa, który go fascynuje, staje się człowiekiem zgubionym. Przeciwnie niż w Ewangelii, która portretuje Iskariotę jako złodzieja i zdrajcę (więcej, wedle Ewangelii nocą wstąpił w niego szatan), u Rostworowskiego zdrajca staje się bezwolny, siłą wciśnięto mu srebrniki, które upadają na ziemię. Judasz ich nie żądał i nie chce ich przyjąć. To pomysł Eleazara, zaakceptowany przez Kajfasza (IV, 4).

Kilka srebrnych monet upada $\mathrm{z}$ brzękiem na ziemię. To się odsłania głębia tragizmu Judasza: człowiek tak słaby, szary, przyziemny, zabobonny, biedny i ograniczony, lękliwy a wyrachowany, nie pozbawiony może dobrych chęci, ale niezdolny do wyższych wzlotów czy poświęceń - poznaje naukę Chrystusa [...] Idzie za głosem porywającej nauki, ale bez głębszego przekonania o jej prawdziwości, bez poznania rzeczywistości objawienia, bez wniknięcia w tajniki łaski. Powtarza słowa Boskiej nauki w sposób jakże opaczny, prostacki i naiwny. Stawszy się ślepym narzędziem mądrzejszych od siebie kapłanów, przygotować ma tryumfalny wjazd Chrystusa do Jerozolimy jako drogę do objęcia tronu w królestwie Izraela. Przeprowadzając intrygę polityczną Judasz jest tylko wykonawcą większej i potężniejszej od niego siły ${ }^{31}$.

${ }^{28}$ J. Starnawski, dz. cyt., s. 423.

${ }^{29}$ Zob. J. Bartyzel, dz. cyt., s. 68.

${ }^{30}$ Zob. tamże, s. 69.

31 J. Starnawski, dz. cyt., s. 436. 
Człowiek zwyczajny, którym był Judasz, został wezwany do życia w cudowności, któremu nie sprostał. I dlatego chleb życia, który dzielił Jezus, stał się dla niego chlebem śmierci (III-1, 3, w. 125). Kresem jego życia staje się sznur, który z pogardą ofiarowuje mu Maria Magdalena:

JUDASZ

Dzisiaj zawisnę na rzemyku, jeśli mi tylko rzemyk dasz.

\section{RACHEL}

spokojnie

Straszysz?

\section{JUDASZ}

nędzny

Nie straszę. Mówię.

\section{MAGDALENA}

gwałtownym ruchem zrywając sznur, którym była przepasana, i rzucając go pod nogi Judasza Masz!

$$
\text { (III-2, 2, w. 262-263) }
$$

Fatalna siła zmusza Judasza do dokonania zdrady - przeciwko sobie. Pomimo błagań Racheli, pomimo wierności Piotra, Jana i pozostałych apostołów, Judasz nie potrafi znaleźć innego rozwiązania. Słyszymy tę pełną goryczy rozpacz w rozmowie z żoną:

\section{JUDASZ}

podnoszac sznur, z gorycza

Przyda się.

[...]

Rachel.

\section{RACHEL}

oparta plecami i futrynę drzwi

Co.

\section{JUDASZ}

Posłuchaj mię.

Ty nie wiesz. Przede mną dziś rozstaje, Mnie kopać grób. We własnej krwie zanurzać ramiona lub szukać zbrodni! 
Człek musi zdradzać albo gnić,

póki go Świątynia w proch nie zetrze!

Rachel. Ty nie wiesz.

(III-2, 3, 264-276)

„Przygoda” z Nazarejczykiem stała się przyczyną upadku Judasza. Gdyby pozostał w rodzinnym Kariocie, mógłby spokojnie dożyć starości, ciesząc się zasłużonym szacunkiem i dobrym imieniem. Jako uczciwy kupiec, z kochającą żoną u boku, mógł w przyszłości zostać nawet burmistrzem Kariothu, ów dobry, poczciwy Judasz. Jednak wicher historii całkowicie zniweczył jego plany.

Przypomnij, Rachel. Ludzie głodni, każdy wskazywał palcem sklep i mówił: „gdy kupić, to u Judy”:

sumienność wag, sumienność miar, a towar lepszy niż zapłata!

I był szacunek. Był i chleb.

I naród męża ci zazdrościł.

$[\ldots]$

Jam cichy był. Co mi krzyk!

Co mi nauka?! Mnie starczyło

w Szabbat... z Rachelą... w cieniu fig...

jeszcze dzieciątko gdzie przy boku...

(III-2, 3, w. 278-293).

Judasz nie miał ambicji, by stać się świętym albo prorokiem (albo innym ,wielkoludem”), marzył o cichym, spokojnym życiu. Być może ten „cień fig”, który wspomina $\mathrm{w}$ rozmowie z żoną, to zapowiedź złośliwości losu. W takim odczytaniu nieszczęsny Judasz staje się niczym... bogobojny Hiob, którego Bóg pozwolił poddać okrutnej próbie. Jednak Hiob przetrwał - nawet wbrew swojej żonie.

Żona Judasza, przeciwieństwo „niewiasty Hiobowej”, nieustannie wzywa Judasza do wierności. Daremne są jednak starania Racheli, która widzi zmianę, jaka nastąpiła w sercu Judasza. Nie wierzy jego zapewnieniom o tym, że Judasz chce iść za Jezusem. Rachela z pogardą patrzy na swego męża, który już przestał walczyć i mentalnie przemienił się w zdrajcę:

\section{RACHEL}

Że masz serce harde

do czasu, że powracasz k’nam

jak pies, co łaski się doprasza, a twoje miejsce teraz tam, u nich, u wrogów Mesyjasza! 


\section{JUDASZ}

Rachel. Posłuchaj. Ja nie wróg.

Ja nędzarz. Sługa waszych sług.

\section{RACHEL}

Tyś sługa, ale pełnej miski

i ręki, która więcej daje.

JUDASZ

Rachel. Szaleństwa jestem bliski!

\section{RACHEL}

W twoje szaleństwo już nie wierzę.

[...]

Zdradzaj! Oszukuj! Byle szczerze!

A tyś bezradny, prosty tchórz!

(III-2, 3, w. 297-311)

Problemem Judasza jest utrata wiary; kupiec wierzył w Jezusa, ale teraz wszystko się zmieniło: „Służyłem mu wytrwale,/ póki nadzieją był gębaty!/ dzisiaj w Nim widzę syna cieśli,/ po którym jeno krzyż zostanie!"' (III, 3, w. 326-329).

W pałacu arcykapłana Judasz, osaczony przez Kajfasza, Annasza i Ananela, nie potrafi zwyciężyć własnego lęku. Samotny w swoim cierpieniu zostaje zmiażdżony przez zwolenników Starego Prawa, saduceuszów i faryzeuszów, których spór Rostworowski przedstawia jako walkę dwóch chórów ${ }^{32}$. W ich oczach Judasz jest szaleńcem, głupcem i tchórzem, który musi zdradzić33. I nawet nie wie, że „mógkby zażądać w tej chwili/ Syjońskich skarbów" (IV, 3, w. 477-478). Arcykapłan Kajfasza dobrze rozumie, jak wielkim zagrożeniem jest nowa nauka, która porywa tłumy i może doprowadzić do zniszczenia władzy Synagogi. Tysiące takich słabych Judaszów, orężnych słowami Mistrza z Nazaretu, wystąpi przeciwko staremu porządkowi, przeciwko tym, którzy posiadają władzę i bogactwa. „Gdy uderzym ławą,/ to im rzeź wyprawim krwawą,/ to ich do milczenia zmuszę" - Kajfasz cytuje słowa

${ }^{32}$ Zob. E. M. Rostworowski, Muzyka do „Judasza” (z listów Marii i Zygmunta Pusłowskich), „Twórczość” 1988, nr 1, s. 96; J. Kuczyńska, cyt., s. 371.

${ }^{33}$ Akt IV to najbardziej dramatyczna część Judasza z Kariothu: „Kontrast słabości, lęku, pokory i nędzy z zimną, przebiegłą potęgą arcykapłanów został uwydatniony w sposób mistrzowski. Judasz chce poprzestać tylko na odstępstwie od Chrystusa, ale broni się przed zdradą, błaga o litość, cierpi niewymownie. Ironia tragiczna sceny polega na tym, że Judasza zmuszają do zdrady ci, którzy stanowią antytezę Chrystusa, a do których zwraca się on w duchu chrześcijańskiej nauki o miłosierdziu. W świetle tego kontrastu i tej ironii tragicznej Judasz staje się dla nas człowiekiem głęboko nieszczęśliwym, z którym można współczuć" (H. Życzyński, dz. cyt., s. 13). 
Judasza, aby potem wybuchnąć: „Ty zmusisz?!! Kogo?!! Ty zmusisz nas?!!/ Ty nędzarz! Ty łachman!!! Ty proch!!! Ty dziad!!!!” (IV, 4, w. 539-543)34.

Ostatnie skrawki wierności i miłości do Chrystusa zostają skruszone w Judaszu. Z lękiem słucha on groźby o ukamienowaniu i ukrzyżowaniu, a potem wpada w spazmatyczny szloch, który zapowiadała „nawiedzona” duchem prorockim Rachel w akcie I dramatu:

On tutaj... on tu sklepik miał...

otwarty... ledwie do wieczora...

(I, 4, w. 400-403)

Teraz Judasz powtarza te same słowa: „Jam... w... Gali... lei...” (IV, 4, w. 546). Jego żona, pojawiająca się w scenie V aktu IV, stanowi dramatyczny kontrapunkt. Przychodzi uwolnić Judasza, ocalić go przed zdradą, ale też przychodzi, by złożyć świadectwo prawdziwej wiary w Chrystusa. Podobnie jak córka Judasza w Mozaice z Noemi Janiny Hertz, tak żona Judasza w sztuce Rostworowskiego jest ostatnim głosem w obronie Iskarioty, ostatnim wołaniem o miłosierdzie dla niego. Obecność Racheli po przesłuchaniu Judasza w pałacu Annasza pełni jeszcze dwie odmienne funkcje: stanowi świadectwo wiary pierwszych chrześcijan, gminy świętych męczenników, którzy nie cofną się w obliczu prześladowań; oraz jest okrutną egzemplifikacją wiary, do której nie dorósł Judasz; on właśnie taki mógł być, taki być powinien! Ale tchórzliwe serce Iskarioty nie jest zdolne do żarliwej wiary w Chrystusa ${ }^{35}$, którą wyznaje Rachela:

Myśmy w głos przepowiadali, że przed wiekami był poczęty i Święty, Święty, zawsze Święty! W głos. I będziemy. O, będziemy dalej! Choćbyście krzyżowali!

My padniemy? Przyjdą inni.

[...]

Najbiedniejsi, najnędzniejsi, ci, na których nikt nie patrzy, a co ziemicę dźwigają... ten proch szary... ta sól ziemi... oni teraz zmartwychwstają!

(IV, 5, w. 637-652)

${ }^{34}$ Zdaniem Popiela trzy siły walczą o duszę apostaty: pragmatyczne nastawienie do rzeczywistości; niezrozumiała siła, która pcha Judasza w stronę Jezusa i leżący poza obrębem jego woli satanizm (zob. J. Popiel, Czy możliwa jest tragedia..., s. 1143-1144).

${ }^{35}$ Dramat Judasza jest „dramatem człowieka uwikłanego w problemy swojej egzystencji i odkrywającego swoją niemoc wobec sytuacji ekstremalnych, jakimi są tu cierpienie i strach przed śmiercią" (W. Kaczmarek, dz. cyt., s. 276). 
Finałowa scena w pałacu arcykapłańskim kończy symboliczny epizod ze złotym kielichem. Kielich arcykapłana Kajfasza, który ze swoją małpią zwinnością przemienia się w sługę szatana, towarzyszy Racheli idącej na męczeńską śmierć. Kielich ten powraca w następnym akcie - paschalnym kielichem „bawi się" zdrajca, pojawiający się w Wieczerniku.

\section{Pascha Judasza}

Ostatni akt Judasza z Kariothu Rostworowskiego to spotkanie Judasza z apostołami w Wieczerniku. Zmęczony Jezus śpi, podczas Jego nieobecności uczniowie z niepokojem oczekują na Paschę. Rozmawiają o zbliżających się wydarzeniach oraz o żonie Racheli. Dramat kreśli zatem apokryf Racheli, którą aresztowano oraz - najprawdopodobniej - skazano na śmierć. Została zabita jako wierna uczennica Chrystusa, ale również jako element szantażu wobec Judasza ${ }^{36}$. Wieść o śmierci dotarła już do Jezusa, który - wedle słów Piotra - ,płakał nad Rachelą” (V, 1, w. 10). Potwierdza to sam Judasz: „Już nią miota/ gdzieś... Już zabrali ją Anieli.../ Już ona... ona się nie stoczy" (V, 1, w. 81-82), chociaż dość niekonsekwentnie, bowiem po chwili dodaje: „Wy Go bierzcie stąd!/ Natychmiast! Wam nic do Racheli!/ On jest ważniejszy" (w. 85-87). A zatem Judasz, jakby w przypływie wiary, w geście wierności, pragnie ocalić Jezusa. Podkreśla to w swoim opracowaniu Starnawski: „Syn zatracenia budzi jeszcze współczucie w ostatniej chwili, gdy zepchnięty na samo dno nędzy i zbrodni, wyznaje wśród łkań Apostołom zgromadzonym w Wieczerniku - szczegół nie podany w Ewangelii - iż wyda Chrystusa z powodu osobistego rozgoryczenia i zawiedzionych nadziei”37. Więcej, „Judasz był człowiekiem, bo rzucił srebrniki!'38 (chociaż sceny z oddaniem srebrników kapłanom nie odnajdziemy w dramacie Rostworowskiego, podobnie próżno szukać pocałunku Judasza oraz jego samobójczej śmierci). Zdaniem Starnawskiego przyczyną tragedii według dramatu Rostworowskiego jest sieć intryg i tchórzostwo Judasza ${ }^{39}$. Co jednak mówi o zdradzie sam Judasz?

Wiecie, kto Go wyda?

Trza wam powiedzieć?... To się przyda.

Już niedaleko.

Po chwili

Wiecie kto?

${ }^{36}$ Zdaniem Życzyńskiego zdrada Judasza dokonuje się „na zimno”, jako akt osobistej zemsty za śmierć Racheli (zob. H. Życzyński, dz. cyt., s. 13).

${ }^{37}$ J. Starnawski, dz. cyt., s. 436.

${ }^{38}$ Zob. tamże, s. 440.

${ }^{39}$ Zob. tamże, s. 434. 
Po chwili, dotykając się palcem piesi, z najzupetniejsza obojętnościa

Ja.

$[\ldots]$

A wiecie czemu? Ja wam powiem.

Wszystko. Spokojnie. Jak się patrzy.

$(\mathrm{V}, 2 \text {, w. 137-140. 144) })^{40}$

Wyznanie Judasza pełne jest sprzeczności. Doskonale oddają to didaskalia, które portretują Iskariotę w scenie II aktu V: Judasz jest złamany, wlokacy nogami, nieśmiało zbliża się do stolu, mówi niepewnym głosem, a po chwili serdecznie albo boleśnie. Namyśla się, wykrzywiajac twarz, jakby miat płakać i rzeczywiście przyciskając pięści do oczów, płacze. Apostołowie ze współczuciem przyjmują wyznania Judasza, tym bardziej, iż niepewny jest los jego żony. Wszyscy podchodza do Judasza z pytaniem: „Nie wróciła?...” (V, 2, w. 80).

Okazuje się, iż w godnym litości Iskariocie kryje się inny człowiek (żeby nie powiedzieć „bestia”). Następuje metamorfoza apostoła, który już nie budzi współczucia, ale lęk. Jest gorączkowy, wybucha, aby po chwili ucichnąć, okazuje gwałtowność, klęka przed Piotrem i błaga go o pomoc, nagle staje się zdziecinniały i spokojny. Nieustanne zmiany emocji można interpretować jako chorobę psychiczną Judasza, co zresztą całkowicie zmieniałoby kwalifikację jego zbrodni. Judasz - zdrajca szalony? A zatem nie jest winien śmierci Jezusa, co w dziele Rostworowskiego potwierdza mocny Sanhedryn, demoniczny Kajfasz i obłudny Ananel (to oni są głównym sprawcą zbrodni) ${ }^{41}$.

Szalone wyjaśnienia Judasza, które apostołowie usłyszeli w Wieczerniku, układają się w dziwaczny ciąg. Iskariota wyjawia, że to on jest zdrajcą. Uczniowie jednak nie podejmują żadnych działań, myślą, że zrozpaczony Judasz wypowiada puste słowa, że to przejaw jego choroby, załamania nerwowego. Jedynie Jan zdaje się rozumieć powagę sytuacji: zdrajca błaga, aby go powstrzymać, człowiek tchórzliwy zna swą słabość i chce, by ktoś mu pomógł ${ }^{42}$. W tej pełnej napięcia scenie Judasz patrzy na Jana strasznym wzrokiem, ale mówi obojętnym tonem: zdradzi Mistrza, ponieważ Ten nie uratował Racheli. Jednak po dtuższej chwili zmienia swoje zeznania:

40 „Interpretując postać Judasza nie można zapominać, że historia apostoła nie ogranicza się do problemu psychologii zdrady. Równie ważny jest dramat człowieka, który fałszywie pojął Chrystusową ideę, dramat spętanego przypadłościami charakteru. Błędem i winą Judasza jest to, że nie podjął próby wyjścia poza kramarską ograniczoność swego charakteru" (J. Popiel, Czy możliwa jest tragedia ..., s. 1138).

${ }^{41}$ Zob. J. Jędrusiak, dz. cyt., s. 231; W. Kaczmarek, dz. cyt., s. 283.

${ }^{42} \mathrm{Na}$ temat stale obecnego strachu w zachowaniu Judasza - zob. J. Popiel, Sztuka dramatyczna Karola Huberta Rostworowskiego, Wrocław 1990, s. 121-123. 
To nieprawda. Nie dlatego.

Ja się tylko z wami dzielę.

Ja tylko tak.

Ciężko dyszy. Z naciskiem

Ja... nie wierzę.

Nic a nic. To jest powód główny.

$$
\text { (V, 2, w. 150-153) }
$$

Brak wiary nie jest w tym przypadku deklaracją ateizmu, ale raczej niewiarą we własne zbawienie ${ }^{43}$. W Judaszu nadal mieszka mentalność starotestamentowa, w której Bóg jest groźny i okrutny. W podziale na zbawionych i potępionych Judasz nie wierzy, że zostanie odkupiony. Taki lękliwy i mały człowiek nie trafi do nieba, to niemożliwe ${ }^{44}$ ! Rzeczywiście, taka postawa jest absolutnie przeciwna nauce Jezusa. Jezus przychodzi, aby dać nadzieję zbawienia dla wszystkich, nade wszystko dla grzeszników, słabych i upadłych. Ale Judasz nie chce o tym pamię$\operatorname{tac}^{45}$.

W ostatnim akcie ponownie padają słowa, które Rachela proroczo powtarzała w Kafarnaum, a potem na wpół obłąkany Judasz bełkotał podczas przesłuchania przed Sanhedrynem; tym razem stanowią one historię powołania Judasza, zapis jego losu:

Nie chciał! Nie chciał! Sklepik miał!

„Chodź”. Poszedł. I... nie nadążył.

Nad siły. - Więc się pogrążył.

(V, 2, w. 169-171)

Tyrady Judaszowe stanowią pomieszanie porządku serca, sumienia i rozumu, jakby równoczesność wszystkich twierdzeń, które ciągną Judasza w przeciwnych

${ }^{43}$ „Wina tragiczna Judasza nie spada na niego w momencie przystąpienia do gminy Chrystusowej [...] lecz stopniowo w nim narasta. [...] Bohater już wówczas uczynił pierwszy fałszywy krok, gdy zrodziła się w nim pewność, że zachowując podstawowe nakazy Prawa, dotyczące zewnętrznej strony bytu, osiągnie Wieczność” (J. Jędrusiak, dz. cyt., s. 226).

${ }^{44}$ Parafrazując myśl Wojciecha Gutowskiego: Judasz wydając Jezusa na ukrzyżowanie, sam zostaje przybity do krzyża swoich marzeń, stąd płynie podwójnie dramatyczna klęska apostaty (zob. W. Gutowski, Mit - Eros - Sacrum. Sytuacje młodopolskie, Bydgoszcz 1999, s. 195).

${ }^{45}$ „Należy podkreślić, że w ujęciu Rostworowskiego zdrada nie przychodzi Judaszowi łatwo. Na drodze do niej przechodzi od stanów zuchwalstwa, grzeszenia, pychy, osądzania czynów i słów Jezusa do zwątpienia, skruchy i rozpaczy. To nie Judasz po zdradę dobrowolnie sięga, przeciwnie, ona przychodzi do bohatera" (J. Popiel, Czy możliwa jest tragedia ..., s. 1144). 
kierunkach. Skonsternowani apostołowie milczą - a Iskariota rzuca im głucho: „Wy... nie wierzcie./ Ja o zdradzie na wiatr gadał” (V, 2, w. 192-193).

Gdy jednak Piotr próbuje pocieszać Judasza, ten groźnym i ochrypłym głosem nie pozwala na litość:

\section{Będzie Królestwo Szatana! \\ I pomsta! Pomsta nad wami! \\ Wyście mnie kamienowali \\ nie kamieniem, a sercami, \\ i mojeście zdruzgotali, \\ że dziś jedna wielka rana!}

(V, 2, w. 202-207)

Agresja Judasza jest tylko maską jego lęku, choć z psychologicznego punktu widzenia Judasz ma rację. Gdyby apostołowie nie byli tacy pobożni, gdyby Rachela nie była tak gorliwa, gdyby wreszcie sam Jezus nie był Mesjaszem wówczas mógłby żyć spokojnie, nikt nie postawiłby go wobec dylematu: męczeństwo albo zdrada! Na tym właśnie polega tragizm Judasza - bohaterstwo lub nikczemność, męczeństwo lub zdrada ${ }^{46}$. Nieodwołalność wyroku, który nad nim ciąży, doprowadza Judasza do obłędu - i tak myślę należy czytać portret zdrajcy Rostworowskiego - nie tyle człowiek szalony zdradza, co bardziej: tchórzliwy Iskariota, mały człowiek, wpada w tryby zbrodniczej machiny, zdradza, i dlatego szaleje. Jest świadom swojej winy, dlatego nie prosi o przebaczenie - Judasz nie jest Dobrym Łotrem, który błaga Jezusa o łaskę, wisząc na krzyżu (zob. Łk 23,42). Ten typ zdrajcy podąża w stronę nicości: Judaszowa odpowiedź na słowa Jana, który unosząc kielich w Wieczerniku, szepce: „Słowo Ciałem się stało...”, to odpowiedź z otchłani potępienia: „I zamieszka... między wami” (V, 4, w. 260261). W tym tragicznym dopełnieniu monologu Jana objawia się szatański demonizm, który sprowokował Judasza do walki z Bogiem i przeznaczeniem ${ }^{47}$.

Warto otwierać księgę Ewangelii, bowiem „w każdym z nas siedzi kawałek tchórzliwego Piotra, okruch niewiernego Tomasza, skrawek Judasza zdrajcy. Warto popatrzeć na apostołów, aby zrozumieć własne życie"48. Warto też stawiać pytanie o wierność, o życie, w którym nie wpadniemy w pułapkę Judasza.

${ }^{46}$ Zob. J. Bartyzel, dz. cyt., s. 70.

${ }^{47}$ Zob. J. Popiel, Wstęp, w: K. H. Rostworowski, Judasz z Kariothu, w: tegoż, Wybór dramatów, oprac. J. Popiel, Wrocław 1992, s. XLIII.

${ }^{48}$ S. Radziszewski, Siedem twarzy Judasza, Kraków 2012, s. 195. 
W Judaszu z Kariothu Rostworowskiego akt zdrady był wynikiem działania wielu motywów, które uruchomiły mechanizm fatum, a później doprowadziły Judasza do zbrodni ${ }^{49}$. Dlaczego nieszczęsny apostoł runął w hańbiącą przepaść zdrady? Niewierny apostoł kroczył drogami doczesności, zaś acedia, obłęd i szaleństwo pchnęły go do finałowej zdrady ${ }^{50}$. Autor dramatu próbuje ukazać wielkość niedoli zdrajcy przez ogromną rozpiętość stylistyczną dzieła: Judasz z Kariothu to tragedia, misterium, oratorium, groteska futurystyczna, dramat naturalistyczny ${ }^{51}$. Tragizm Judasza to tragizm całego rodzaju ludzkiego, który rozpoczął się w momencie wygnania człowieka z Raju ${ }^{52}$. I owszem, w dramacie Rostworowskiego dokonuje się swoista „rehabilitacja” Judasza, ale rozumiana jedynie jako pewien rodzaj wyrozumiałości dla tajemnicy duszy ludzkiej, którą jest niezawiniona wina ${ }^{53}$. W tle dramatu czytelnik odczuwa istnienie powołania do zdrady, demoniczny rodzaj anty-łaski: predestynacja Judasza do zdrady stanowi konieczny element soteriologicznego planu Stwórcy ${ }^{54}$.

$\mathrm{Z}$ drugiej jednak strony Judasz Rostworowskiego to postać pospolita i słaba, dokonująca zdrady przez zastraszenie i słabość woli ${ }^{55}$, to po prostu „mały człowiek", jak pisze ks. Michał Klepacz ${ }^{56}$, to dusza przyziemna, człowiek małej wiary ${ }^{57}$. A nawet kuzyn Judasza Kazantzakisa, który w Ostatnim kuszeniu Chrystusa z nienawiścią mówi o swoim Mistrzu: „Niech mu Bóg przebaczy - Bóg, bo ja nie potrafię. Niech spadną na jego głowę krew, łzy i prochy Izraela!" 58 .

W literaturze polskiej kontynuatorem medytacji o Judasza jest Ireneusz Iredyński ze swoim dramatem Żegnaj, Judaszu ${ }^{59}$. Tytułowe Witaj, Judaszu, które umieściłem w niniejszym opracowaniu, to echo słów Zmartwychwstałego Chrystusa, skierowanych do pełnych lęku niewiast w dniu zmartwychwstania (zob. Mt 28,9). Tych słów Judasz nie usłyszał. A jednak właśnie to Jezusowe wezwanie

${ }^{49}$ Zob. J. Jędrusiak, dz. cyt., s. 227.

${ }^{50}$ Zob. tamże, s. 228.

${ }^{51}$ Zob. J. Bartyzel, dz. cyt., s. 89.

${ }^{52}$ Zob. J. Popiel, Czy możliwa jest tragedia ..., s. 1146.

${ }^{53}$ Zob. J. Bartyzel, dz. cyt., s. 88.

${ }^{54}$ Zob. tamże, s. 99.

${ }^{55}$ Zob. W. Kaczmarek, dz. cyt., s. 290.

${ }^{56}$ M. Klepacz, Karol Hubert Rostworowski, Wilno 1938, s. 88, cyt. za: J. Jędrusiak, dz. cyt., s. 230 .

${ }^{57}$ Zob. J. Popiel, Czy możliwa jest tragedia..., s. 1136.

${ }^{58}$ N. Kazantzakis, Ostatnie kuszenie Chrystusa, tł. J. Wolff, Poznań 1992, s. 446.

${ }^{59}$ Warto przywołać autokomentarz Iredyńskiego dotyczące jego „nowego” Judasza: „Żegnaj Judaszu to sztuka o człowieku cierpiącym, zgniecionym przez mechanizmy społeczne. Judasz jest człowiekiem, któremu należy współczuć [...] napisałem sztukę o konflikcie jednostki i pewnej społeczności, sztukę o wierności zasadom i zdeptaniu tej wierności” (Nie pisze przewodnika po życiu. Rozmowa Ireneusza Iredyńskiego z Anna Schiller (nagrana w 1973 r.), „Dialog” 1987, nr 6, s. 124). 
stanowi najlepszą glosę do suigenerischrystofanii w ostatniej scenie dramatu Rostworowskiego. W otwartych drzwiach ukazuje się wyczerpany, wynędzniaty Chrystus, z oczami pełnymi smutku i miłości, oświecony purpurowym blaskiem zachodzacego słońca - i patrzy na apostołów w Wieczerniku. Również na Judasza.

Istnieje Golgota Jezusa oraz Golgota zbrodniarza ${ }^{60}$, wszystko wpisane w jeden plan zbawienia.

\section{Bibliografia}

Bartyzel Jacek, ,Judasz z Kariothu” Karola Huberta Rostworowskiego. Dzieje recepcji scenicznej i krytycznoliterackiej (1913-1981), w: Dramat biblijny Młodej Polski, red. Stefan Kruk, Wrocław 1992.

Eustachiewicz Lesław, Wokót K. H. Rostworowskiego, „Dialog” 1969, nr 6.

Gutowski Wojciech, Mit-Eros - Sacrum. Sytuacje mtodopolskie, Wyd. Homini, Bydgoszcz 1999.

Hertz Janina, Mozaika z Noemi, Warszawa 1984.

Iredyński Ireneusz, Nie pisze przewodnika po życiu. Rozmowa Ireneusza Iredyńskiego z Anna Schiller (nagrana w 1973 r.), „Dialog” 1987, nr 6.

Iredyński Ireneusz, Żegnaj, Judaszu..., „Dialog” 1965, nr 9.

Jędrusiak Joanna, Motyw Judasza w dramacie Młodej Polski, w: Dramat biblijny Młodej Polski, red. S. Kruk, Wrocław 1992.

Kaczmarek Wojciech, Zdrada i wiara (Karol Hubert Rostworowski), w: tegoż, Złamane pieczęcie Księgi. Inspiracje biblijne w dramaturgii Młodej Polski, RW KUL, Lublin 1999.

Kuczyńska Jadwiga, $Z$ dziejów scenicznych dwu dramatów o Judaszu, w: Biblia a literatura, red. Stefan Sawicki, Jan Gotfryd, Lublin 1986.

Popiel Jacek, Czy możliwa jest tragedia chrześcijańska? (, Judasz z Kariothu” Karola Huberta Rostworowskiego), „Znak” 1984, nr 8-9.

Popiel Jacek, Szkic biografii Karola Huberta Rostworowskiego, „Znak” 1984, nr 8-9.

Popiel Jacek, Sztuka dramatyczna Karola Huberta Rostworowskiego, Wyd. Wiedza o kulturze, Wrocław 1990.

Popiel Jacek, Wstęp, w: Rostworowski Karol Hubert, Judasz z Kariothu, w: tegoż, Wybór dramatów, oprac. J. Popiel, Wrocław 1992.

Radziszewski Stefan, Siedem twarzy Judasza, Kraków 2012.

Radziszewski Stefan, Raport w sprawie Judasza (Janiny Hertz słowo w obronie apostoła), w: W kręgu apokryfów, red. Edward Jakiel, Janusz Mosakowski, Gdańsk 2015.

${ }^{60}$ Zob. J. Jędrusiak, dz. cyt., s. 232. 
Rostworowski Emanuel M., Muzyka do „Judasza” (z listów Marii i Zygmunta Pusłowskich), „Twórczość” 1988, nr 1.

Rostworowski Karol Hubert, Judasz z Kariothu, w: tegoż, Wybór dramatów, oprac. J. Popiel, Wrocław 1992.

Sellier Philippe, Biblia w kulturze Zachodu, tt. Ewa Burska, IW PAX, Warszawa 2012.

Starnawski Jerzy, Tragizm ,,Judasza” Rostworowskiego, „Przegląd Powszechny" 1951 , t. 231.

Walas Teresa, Dynamika wewnętrzna światopogladu Młodej Polski, w: Porównania. Studia o kulturze modernizmu, red. R. Zimand, PIW, Warszawa 1983.

Życzyński Henryk, Twórczość Karola Huberta Rostworowskiego, Towarzystwo - Uniwersytet Wiedzy Chrześcijańskiej, Lublin 1938.

\section{Streszczenie \\ Witaj, Judaszu. Dramat zagubionego apostoła w Judaszu z Kariothu Karola Huberta Rostworowskiego}

Dramat Judasz z Kariothu Karola Huberta Rostworowskiego stanowił przedmiot badań wielu badaczy (Sławińska, Pigoń, Starnawski, Popiel, Kaczmarek). To oryginalne dzieło, z genialną kreacją aktorską Ludwika Solskiego, w którym autor poszukuje prawdy o apostole zdrajcy. Rostworowski nie idzie drogą swoich poprzedników, według których Judasz zdradza Jezusa, ponieważ chce zmusić Go do podjęcia walki politycznej, albo zdradza, ponieważ widzi w Nim konkurenta do serca Marii Magdaleny. Wersja Rostworowskiego to opowieść o człowieku, który był słaby i mały, a jego tchórzliwe serce nie było zdolne unieść wielkości orędzia Jezusa z Nazaretu. Nie oznacza to bynajmniej, że Rostworowski - wbrew wersji biblijnej - dokonuje rehabilitacji Judasza. Świadkami oskarżenia przeciwko Iskariocie jest Rachela - jego żona, oraz Jan apostoł, którzy do końca chcą ocalić go przed dokonaniem zbrodni. Dramat zdrady zamyka się sceną spotkania Judasza z apostołami w Wieczerniku, a zatem Rostworowski opuścił wydarzenia znane z Ewangelii: pocałunek Judasza, oddanie srebrników kapłanom, samobójczą śmierć. Takie „zawieszenie” samego aktu zdrady wprowadza czytelnika/widza w swoisty stan oczekiwania, w którym ukryte jest pytanie: A jakim rodzajem zdrajcy jesteś Ty? 


\section{Summary \\ Hello, Judas. Drama of the lost apostle in Karol Hubert Rostworowski's "Judas of Karioth"}

Karol Hubert Rostworowski's play Judas of Kerioth (Judasz z Kariothu) has been analysed by a number of scholars (Sławińska, Pigoń, Starnawski, Popiel, Kaczmarek). A unique work, known for the brilliant stage performance by Ludwik Solski, it reflects the author's search for truth about the traitor-apostle. Rostworowski does not follow the path chosen by his predecessors, who believed that Judas betrayed Jesus to get him involved in political struggle, or because he saw in him a rival for the heart of Mary Magdalene. Rostworowski's is a story of a man who was weak and small-minded, and whose cowardly heart was unable to bear the greatness of the message brought by Jesus of Nazareth. It does not follow from this, however, that Rostworowski rehabilitates Judas in defiance of the biblical account. The witnesses for the prosecution in the case against him are Rachel, his wife, and John the Apostle. They both try to save Judas from committing the deed until the very end. In the closing scene, Judas meets the other apostles in the Cenacle. Thus Rostworowski omitted a number of events known from the Gospel: the Judas kiss, returning of the silver to the priests, the suicide. With the very act of betrayal thus 'suspended', the reader/audience is left in a state of anticipation where the underlying question is: But what kind of a traitor are you? 